\title{
MOLECULAR STAGING OF PROSTATIC CANCER WITH RT-PCR ASSAY FOR PROSTATE-SPECIFIC ANTIGEN IN PERIPHERAL BLOOD AND LYMPH NODES. 5 YEAR FOLLOW-UP
}

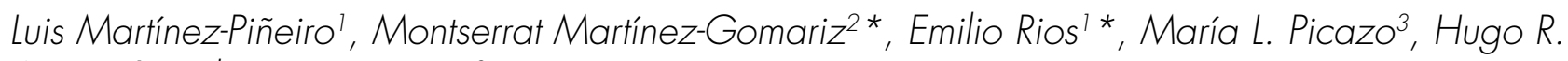
Arriaga ${ }^{7}$ and Rosario Perona².

'Urology Service and '3epartment of Pathology, La Paz University Hospital. Autonomous University of Madrid and 2Instituto de Investigaciones Biomédicas CSIC. Spain.

*Both authors made equivalent contribution to this publication.

Summary.- OBJECTIVE: Thirty percent of patients with localized prostate cancer undergoing radical prostatectomy experience biochemical recurrence with rising serum prostate-specific antigen (PSA). More than $50 \%$ of these develop distant metastases.

METHODS: Presence of PSA mRNA in pathologically normal pelvic lymph nodes from 154 patients undergoing radical prostatectomy was investigated with nonquantitative PSA reverse transcriptase polymerase chain reaction (RT-PCR). In 135 of these patients preoperative serum PSA RT-PCR was also assessed. RT-PCR positivity was correlated with biochemical recurrence and compared with other clinical risk factors.
Luis Martínez-Piñeiro

Pza. Conde Valle Suchil, 17 - 1B 28015 Madrid. (Spain)

luis@martinez-pineiro.com

Accepted for publication: April 19, 2007.
RESULTS: At a median follow-up of 58 months the biochemical failure-free survival of patients with positive versus negative lymph node RT-PCR was $68.4 \%$ and $76.7 \%$ respectively $(p=0.2)$. Biochemical failure-free survival was not influenced by the serum PSA RT-PCR result either (72.3\% versus $72.6 \%)$. Surgical margin status, preoperative serum PSA, pT category and Gleason score were independent prognostic risk factors for biochemical recurrence with a hazard ratio of 5.48, 2.56, 2.56 and 2.13 respectively.

CONCLUSIONS: At 5 year follow-up after radical prostatectomy, both serum and lymph node RT-PCR are not correlated with biochemical failure-free survival. Established clinical risk factors have a much stronger impact on biochemical recurrence.

Keywords: Prostate. Cancer. RT-PCR. Lymph node. Blood.

Resumen.- OBJETIVO: El 30\% de los pacientes con cáncer de próstata localizado sometidos a prostatectomía radical sufren recurrencia bioquímica con aumento del antígeno prostático específico (PSA). Más del 50\% de ellos desarrollan metástasis a distancia.

MÉTODOS: Utilizando la prueba de reacción en cadena de polimerasa con transcriptasa inversa (RT-PCR) se investigó en 154 pacientes sometidos a prostatectomía radical la presencia de mRMA de PSA en ganglios linfáticos normales según el análisis anatomopatológico. En 135 pacientes también se evaluó la RT-PCR de PSA preoperatoria en sangre periférica. Se correlacionó un resultado positivo de RT-PCR con recurrencia bioquímica y se comparó con otros factores de riesgo clínicos. 
RESULTADOS: La supervivencia libre de recurrencia bioquímica en los pacientes con RT-PCR positiva y negativa en ganglios linfáticos fue de $68,4 \%$ y $76,7 \%$ respectivamente $(p=0,2)$, con una mediana de seguimiento de 58 meses.

El resultado de RT-PCR en suero no influyó en la supervivencia libre de recurrencia bioquímica en ninguno de los grupos (72,3\% frente a 72,6\%). El estado de los márgenes quirúrgicos, el PSA sérico preoperatorio, la categoría pT y el escore de Gleason fueron factores de riesgo independientes para el pronóstico de recurrencia bioquímica con un riesgo relativo de 5,48, 2,56, y 2, 13 respectivamente.

CONCLUSIONES: Ni la RT-PCR de PSA sérica ni la de ganglios linfáticos se correlacionan con supervivencia libre de recidiva bioquímica a los cinco años de seguimiento después de prostatectomía radical. Factores de riesgo clínico establecidos tienen un impacto mucho más fuerte sobre la recurrencia bioquímica.

Palabras clave: Próstata. Cáncer. RT-PCR. Ganglios linfáticos. Sangre.

\section{INTRODUCTION}

PSA reverse transcriptase polymerase chain reaction (RT-PCR) has been performed on peripheral blood and bone marrow, showing sensitivities of detection of PSA expressing cells ranking from $0 \%$ to $92 \%$ (1-3). Although some studies have correlated the RT-PCR results with biochemical failure (4-7) the great variation in sensitivity of this assay has lead many institutions to abandon this technique as a preoperative and retrospective staging method. However, results of prospective and retrospective series utilizing fresh and paraffin-embedded archived lymph node tissue have shown a good correlation between lymph node RT-PCR positivity and biochemical recurrence (8-11). Very recently Ferrari et al (12) demonstrated that quantitative RT-PCR on lymph node tissue is an independent prognostic marker of disease recurrence.

In the past, we have shown lymph node PSA RT-PCR to correlate with Gleason score and the presence of Gleason patterns 4 or 5 (13). In the present manuscript we report on the follow-up of this cohort of patients who were staged with RT-PCR for PSA in peripheral blood and lymph nodes. We correlate RTPCR results with biochemical recurrence, testing the hypothesis that a positive RT-PCR in blood and/or lymph nodes might reveal occult metastases predictive of subsequent progression.

\section{MATERIAL AND METHODS}

\section{Clinical specimens}

Retrieval of clinical specimens has been already described in a previous manuscript (13). 154 patients were prospectively recruited from La Paz University Hospital outpatient urology clinic between October 1995 and October 1999. Samples were obtained according to an Internal Review Board approved protocol of the Committee of Ethics and Clinical Investigation and informed consent for specimen collection was obtained from each patient. All patients had newly diagnosed clinically localized prostate cancer (T1-T3Mo, 1997 International Union Against Cancer classification) and underwent radical retropubic prostatectomy and bilateral lymphadenectomy of the obturator and external iliac nodes. In 12 patients only lymphadenectomy of the obturator region was performed and nodes from the external iliac region were not included in the dissection. 25 patients received preoperative androgen deprivation before surgery. Preoperative peripheral blood samples and lymph nodes were assessed with PSA RT-PCR in 135 patients. Pelvic lymph nodes only were assessed with PSA RT-PCR in 19 patients. Lymph nodes were prepared immediately after retrieval, snap frozen in liquid nitrogen and kept at $-70^{\circ} \mathrm{C}$ until RNA extraction (13).

\section{RT reaction and nested $P C R$}

Two sets of primers were used for the nested polymerase chain reaction as described by Israeli et al. (14). RT reaction and nested PCR has been described in a previous manuscript (13). In each set of reactions, a negative control and a positive control were assayed. The detection limit of our PCR protocol was determined with serial dilutions, establishing a sensitivity of one LNCaP cell out of $10^{6}$ Jurkat cells.

\section{Clinical Follow-up}

Disease assessment every 6 months included serum PSA, clinical progression and/or initiation of hormone therapy. Biochemical failure was defined as the first date that the serum PSA reached $0.2 \mathrm{ng} / \mathrm{ml}$ or higher, confirmed by a second determination (15). Patients with histologically confirmed metastasis in lymph nodes were treated with postoperative androgen ablation and were not included in the survival analysis. $\mathrm{pNO}$ patients received postoperative radiotherapy and/or androgen ablation only if biochemical failure was established by at least two serum PSA values above $0.2 \mathrm{ng} / \mathrm{ml}$.

\section{Statistical analysis}

Quantitative data are expressed as mean (SD) or median (range) values and qualitative data as percentages. 
Kaplan-Meier curves of biochemical failure-free survival were calculated with the following risk factors: Preoperative serum PSA concentration less than 10 $\mathrm{ng} / \mathrm{ml}$ or $10 \mathrm{ng} / \mathrm{ml}$ or greater; biopsy and/or specimen Gleason score less than 7, equal to 7 or higher than 7; pT category equal to pT2 or pT3-4; negative or positive surgical margins. Differences between curves were assessed by log-rank test.

Univariate Cox regression time-to-biochemical-failure analysis was calculated for the following prognostic factors: preoperative serum PSA $<<10 \mathrm{ng} /$ $\mathrm{ml}$ versus $>10 \mathrm{ng} / \mathrm{ml}$ ), Gleason score in biopsy and specimen, presence of Gleason pattern 4 or 5 in biopsy or specimen, number of positive biopsies, presence of perineural invasion in specimen, $T$ (T1 versus $T 2-3$ ) and pT category (pT2 versus pT3-4), number of lymph nodes removed, surgical margin status, preoperative RT-PCR result in serum and/or lymph nodes. Multivariate Cox regression time-to-biochemical-failure analysis was calculated with the factors that showed a $p$ value $<0.25$ in univariate analysis, in order to adjust for statistically significant prognostic factors. The relative risk was defined as the proportional increase in biochemical failure expected with a given prognostic factor, after adjusting for the other variables in the model. All statistical tests performed were two sided with significance level 0.05, using the SPSS statistical software version 11 .

\section{RESULTS}

Mean age of the 154 patients was 64.7 years \pm 5.7. 3 patients were lost to follow-up and not included in the statistical analysis. Clinical characteristics of the patients are shown in Table I. Overall biochemical failure-free survival with 5-years followup was $73.4 \%$ (Table II). Results of Cox regression uni and multivariate analysis are depicted in Table III. Only serum PSA concentration, Gleason score of the specimen, surgical margin status and pT category were significant independent prognostic risk factors. The lymph node RT-PCR result was not significant in the univariate $(p=0.194)$ or multivariate analysis. Kaplan Meier curves of the most significant independent prognostic risk factors are depicted in Figures 1-3. Biochemical failure-free survival was not influenced by the RT-PCR result in blood or lymph nodes.

\section{Relationship of biochemical failure-free survival to serum PSA RT-PCR result}

Among the 135 patients with preoperative serum PSA RT-PCR evaluation 127 were pNO with conventional and immunohistochemical analysis (13). Median follow-up of this group of patients was 58.4 months (range 11-77). 120 patients had a follow-up greater than 40 months. 2 died due to non-specific related causes at 28 and 44 months and both were free of disease until death. Univariate analysis (Table 3) demonstrated that biochemical failure-free survival was not influenced by the serum PSA RT-PCR result $(p=0.601)$. Biochemical failure-free survival by serum PSA RT-PCR result is shown in Table II.

\section{Relationship of biochemical failure-free survival to lymph node PSA RT-PCR result}

Among the 151 patients with lymph node PSA RT-PCR evaluation, 143 were $\mathrm{pNO}$ with conventional and immunohistochemical analysis (13). 8 patients with lymph node metastasis in histological as-

\section{TABLE I. CLINICAL CHARACTERISTICS OF THE PATIENTS.}

\begin{tabular}{|c|c|}
\hline Characteristic & No. (\%) \\
\hline Serum PSA $\mathrm{n} / \mathrm{ml}$ & 151 \\
\hline$<10$ & $100(66.2)$ \\
\hline$>10-20$ & $37(24.5)$ \\
\hline$>20$ & $14(9.3)$ \\
\hline Tumour stage & 151 \\
\hline Tla-c & $88(58.4)$ \\
\hline T2-3 & 63 (41.7) \\
\hline pT2 & $100(66.2)$ \\
\hline pT3-4 & $51(33.8)$ \\
\hline Positive margins & $45(29.8)$ \\
\hline pN1 & $8(5.3)$ \\
\hline Gleason score biopsy* & 150 \\
\hline$<7$ & $122(80.8)$ \\
\hline 7 & 21 (13.9) \\
\hline $8-10$ & $7(4.6)$ \\
\hline Gleason score specimen* & 150 \\
\hline$<7$ & $85(56.3)$ \\
\hline 7 & $52(34.4)$ \\
\hline $8-10$ & $13(8.6)$ \\
\hline
\end{tabular}

* 1 patient with preoperative androgen blockage and no known biopsy Gleason score is not included. 
sessment were treated with postoperative androgen ablation and not included in the biochemical failurefree survival analysis. Median follow-up of the 143 evaluable patients was 57.5 months (range 11-77). 134 patients had a follow-up greater than 40 months. 3 died of non-specific related causes at 19, 20

\section{TABLE II. BIOCHEMICAL FAILURE-FREE SURVIVAL (BFFS) AT 5-YEARS FOLLOW-UP IN pNO PATIENTS: RELATIONS-} HIP TO RISK FACTORS.

\begin{tabular}{|c|c|c|c|}
\hline Category & No. (\%) & BFFS (\%) & $\mathbf{P}^{*}$ \\
\hline Overall & 143 & $105(73.4)$ & \\
\hline Serum PSA (ng/ml) & 143 & & \\
\hline$<10$ & 95 & $77(81.1)$ & \\
\hline$>10$ & 48 & $28(58.3)$ & 0.003 \\
\hline Gleason score biopsy** & 142 & & \\
\hline$<7$ & 120 & 92 (76.7) & \\
\hline 7 & 15 & $9(60.0)$ & \\
\hline $8-10$ & 7 & $3(42.9)$ & 0.002 \\
\hline Gleason score specimen ** & 142 & & \\
\hline$<7$ & 85 & $73(85.9)$ & \\
\hline 7 & 45 & $26(57.8)$ & \\
\hline $8-10$ & 12 & $5(41.7)$ & $<0.001$ \\
\hline Tumour stage & 143 & & \\
\hline pT2 & 100 & $77(77.0 \%)$ & \\
\hline pT3-4 & 43 & $28(65.1 \%)$ & 0.207 \\
\hline Surgical margin & 143 & & \\
\hline negative margin & 102 & $86(84.3)$ & \\
\hline positive margin & 41 & $19(46.3)$ & $<0.001$ \\
\hline Lymph node PSA RT-PCR & 143 & & \\
\hline Negative in all nodes & 86 & $66(76.7)$ & \\
\hline Positive in any node & 57 & $39(68.4)$ & 0.2 \\
\hline Serum PSA RT-PCR & 127 & & \\
\hline negative & 62 & $45(72.6)$ & \\
\hline positive & 65 & $47(72.3)$ & 0.9 \\
\hline Serum and lymph node PSA RT-PCR & 127 & & \\
\hline negative in serum and lymph node & 103 & $77(74.8)$ & \\
\hline positive in serum or lymph node & 24 & $15(62.5)$ & 0.2 \\
\hline
\end{tabular}

* Log-rank tests were used to assess $P$ values

* 1 patient with preoperative androgen blockage and no known biopsy Gleason score is not included 


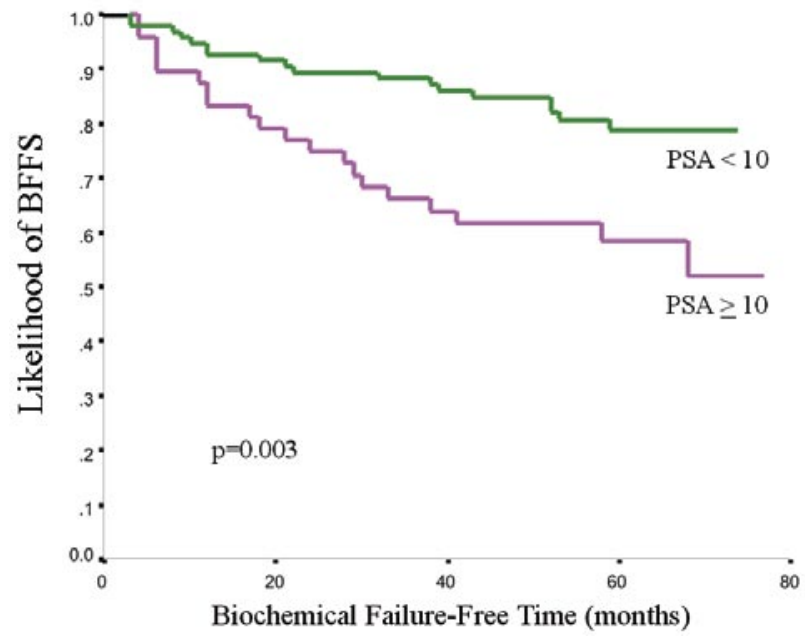

Figure 1. Kaplan-Meier biochemical failure-free survival (BFFS) curves for pNO patients with preoperative serum PSA less than $10 \mathrm{ng} / \mathrm{ml}$ or $10 \mathrm{ng} / \mathrm{ml}$ or greater ( $p=0.003$ )

and 44 months and were free of disease until death. Univariate and multivariate analysis (Table 3) demonstrated that biochemical failure-free survival was not influenced by the lymph node PSA RT-PCR result. Kaplan-Meier biochemical failure-free survival (BFFS) curves for $\mathrm{pNO}$ patients with negative or positive lymph node PSA RT-PCR is shown in Figure 4. Biochemical failure-free survival by lymph node PSA RT-PCR result is shown in Table II.

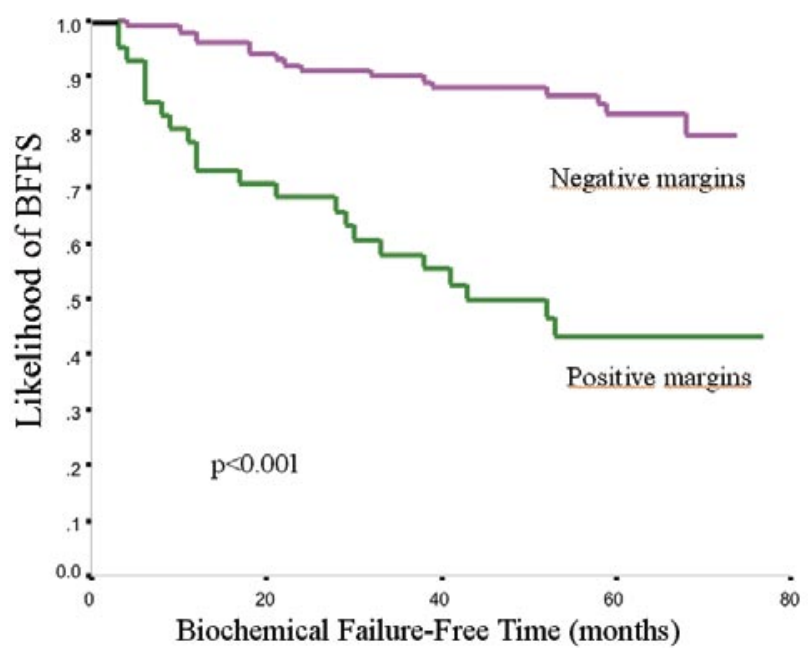

Figure 3. Kaplan-Meier biochemical failure-free survival (BFFS) curves for pNO patients with negative or positive surgical margins $(p<0.001)$.

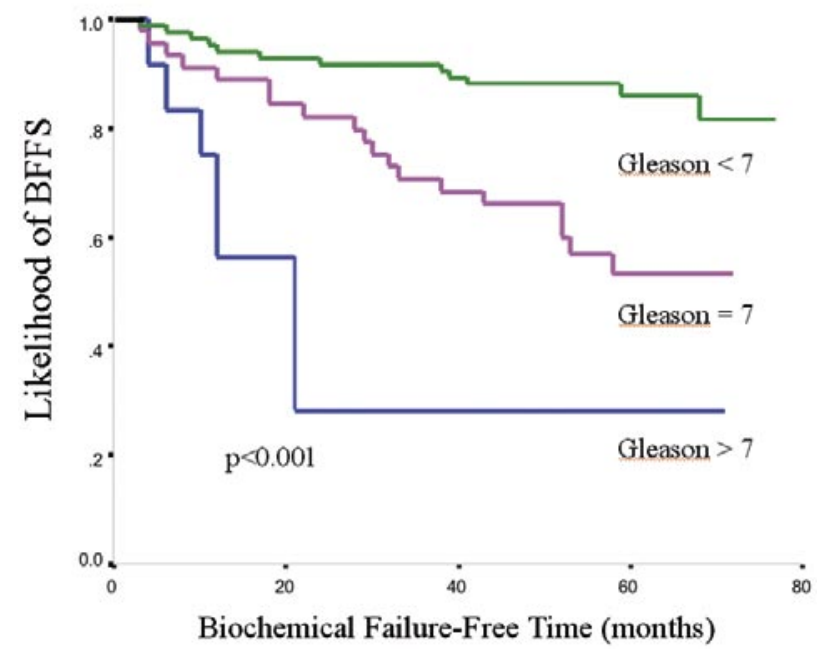

Figure 2. Kaplan-Meier biochemical failure-free survival (BFFS) curves for pNO patients with specimen Gleason score less than 7 , equal to 7 or higher than 7 $(p<0.001)$

\section{Relationship of biochemical failure-free survival to lymph node and serum PSA RT-PCR result}

Among the 143 patients who were classified as pNO, 127 had preoperative serum PSA and lymph node tissue analyzed by RT-PCR. Median follow-up of this cohort of patients was 58.4 months (range 11-77). Univariate and multivariate analysis (Table III) demonstrated that biochemical failure-free survival was not negatively influenced in patients with both

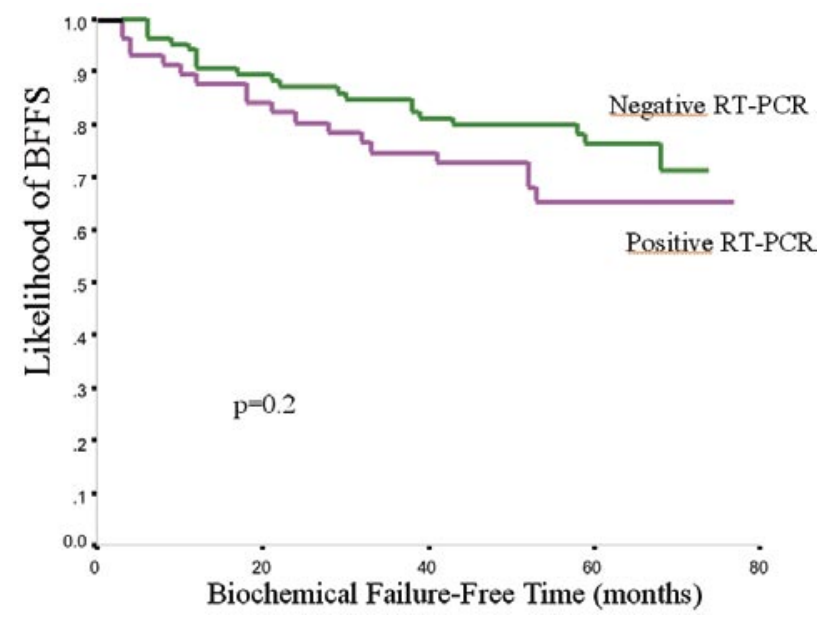

Figure 4. Kaplan-Meier biochemical failure-free survival (BFFS) curves for pNO patients with negative or positive lymph node PSA RT-PCR ( $p=0.2)$. 
serum and lymph node positive PSA RT-PCR results. Biochemical failure-free survival by the combination of serum and lymph node PSA RT-PCR results is shown in Table II.

\section{DISCUSSION}

During the last decade several methods have been evaluated to better diagnose patients with apparently localized prostate cancer but harboring occult metastases. Immunohistochemical evaluation of regional lymph nodes has demonstrated its superiority over routine hematoxylin and eosin staining in the detection of lymph node metastasis in some studies, particularly in patients with locally advanced prostate cancer (16-18). Four to $16 \%$ of pT3pNO patients have occult lymph node metastases when their lymph nodes are analyzed using antibodies to PSA and epithelial specific intermediate filament cytokeratins.

PSA RT-PCR has also been evaluated to detect submicroscopic metastases. Although initially serum PSA RT-PCR showed promise as a novel way to stage patients with localized prostate cancer, the poor correlation with disease progression made most groups abandon this technique. Most institutions that initially reported a good correlation of serum PSA RT-PCR with biochemical failure $(5,19-21)$ are not using RT-PCR as a routine staging method anymore, because it has not shown superiority over classical histological clinical risk factors.

Very few institutions have evaluated the role of RT-PCR for detection of disseminated prostate cells in pelvic lymph nodes $(8,22-28)$. The conclusions of such studies are controversial. Results of small prospective (9) and retrospective (8) series utilizing fresh and paraffin-embedded archived lymph node tissue respectively have shown a good correlation between RT-PCR lymph node positivity and biochemical recurrence. However a larger retrospective study including 102 men with seminal vesicle invasion, negative lymph nodes at radical prostatectomy and a cancer progression rate of $71 \%$ at 10 years found just $2.9 \%$ of patients with positive lymph node RT-PCR (28). On the other hand, the largest prospective study so far showed a $28 \%$ RT-PCR lymph node positivity rate with a good correlation with standard pathological risk factors (25). This group has recently updated the results of their prospective study and has demonstrated that quantitative PSA RT-PCR in lymph nodes is an independent risk factor for biochemical recurrence (12). Semi-quantitative conventional RT-PCR assay for sensitively detecting PSA mRNA in non-metastasized lymph nodes, using the same RNAs used in their last published study, however, was not informative about biochemical recurrence risk (12).
In 2003 we published our initial experience with non-quantitative PSA RT-PCR performed in lymph node tissue and peripheral blood (13). Our initial results with lymph node RT-PCR were promising. Lymph node RT-PCR had a statistically significant correlation with Gleason score. However serum PSA RT-PCR had a poor correlation with serum PSA and histological risk factors.

Quantitative RT-PCR was developed during the late 1990's, while we were starting our prospective study (13). At that time no published information was available about the utility and precision of quantitative RT-PCR in the staging of prostate cancer patients. Although we were aware of this new technology, most groups (including ours) at that time used non-quantitative PSA RT-PCR assays and we decided to complete the study with the non-quantitative method. Regretfully after a median follow-up of 5 years we have shown that both serum and lymph node PSA RT-PCR are not independent risk factors for biochemical failure. Serum PSA RT-PCR was far from significant in the univariate analysis (Table III) and it confirms the observations published in our previous study (13), namely that it was not correlated with clinical risk factors and was even inversely correlated with preoperative serum PSA and lymph node status. Lymph node PSA RT-PCR, which had a statistically significant correlation with Gleason score in our initial evaluation (13) and could be an independent risk factor, has not fulfilled our expectations. After 5 years follow-up, patients with negative lymph node RT-PCR have a lower biochemical failure rate (Figure 4), but the difference does not reach statistical significance. This difference may become significant with longer follow-up, but it is clear that clinical risk factors used in the everyday practice, such as preoperative serum PSA, Gleason score, pT category and surgical margin status have a much stronger impact on biochemical failure-free time than non-quantitative RT-PCR (Figure 1-3, Table 3). A similar lack of quantitative precision likely limited the predictive value of previous studies using non-quantitative RT-PCR analysis (14,29-31) and very few groups have shown non-quantitative RT-PCR to be an independent risk factor associated with tumour progression (10). Quantitative RT-PCR, as the new standard, provides quantitative accuracy due to both the methodology and to normalization of each PSA copy value to a more constantly expressed housekeeping gene control (e.g. GAPDH) for PSA integrity and amplification efficiency (32) and already has been shown to be an independent risk factor for tumour progression (12). However we need more studies showing the usefulness of quantitative PSA RT-PCR in this regard and even more important, we need to find a more simple method of detecting submicroscopic metastasis that can be used in routine clinical practice 


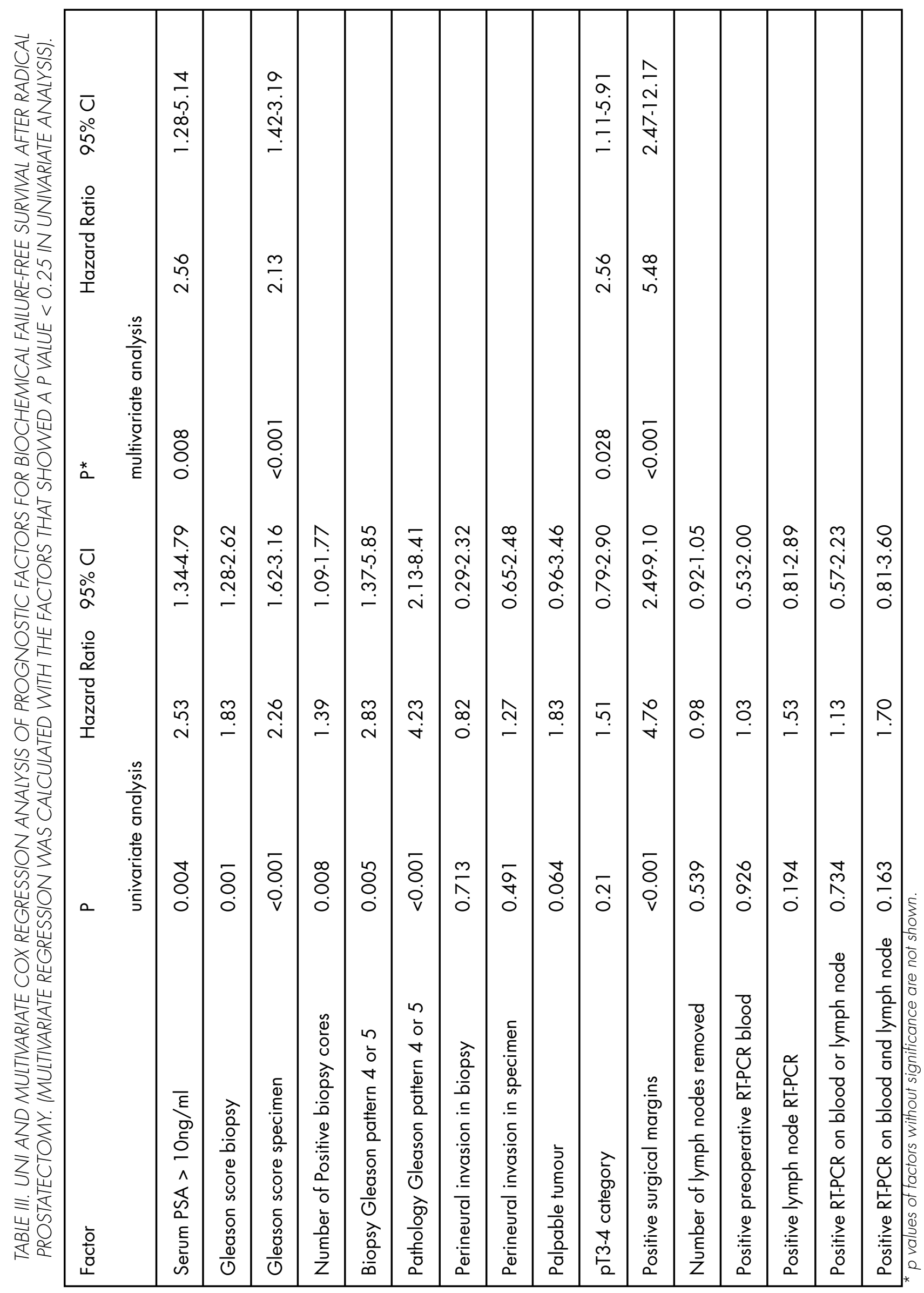


without the need for a specifically devoted research unit.

\section{CONCLUSIONS}

At 5 year follow-up after radical prostatectomy, both serum and lymph node non-quantitative RTPCR are not correlated with biochemical failure-free survival. Serum PSA RT-PCR was far away from significance. Patients with negative lymph-node RT-PCR had a lower biochemical failure rate, but the difference did not reach statistical significance.

\section{ACKNOWLEDGMENTS}

We express special thanks to Rosario Madero for assistance in the statistical analysis.

\section{REFERENCES AND RECOMENDED READINGS (*of special interest, ${ }^{* *}$ of outstanding interest)}

*1. COREY, E.; COREY, M.J.: "Detection of disseminated prostate cells by reverse transcription-polymerase chain reaction (RT-PCR): Technical and clinical aspects". Int. J. Cancer,77: 655, 1998.

2. GOMELLA, L.G.; RAJ, G.V.; MORENO, J.G.: "Reverse transcriptase polymerase chain reaction for prostate specific antigen in the management of prostate cancer". J. Urol., 158: 326, 1997.

3. OLSSON, C.A.; DE VRIES, G.M.; BUTTYAN, R. y cols.: "Reverse transcriptase-polymerase chain reaction assays for prostate cancer". Urol. Clin. North Amer., 24: 367, 1997.

4. DE LATAILLE, A.; OLSSON, C.A.; BUTTYAN, R. y cols.: "Blood-based reverse transcriptase polymerase chain reaction assays for prostatic specific antigen: Long term follow-up confirms the potential utility of this assay in identifying patients more likely to have biochemical recurrence (rising PSA) following radical prostatectomy". Int. J. Cancer, 84: 360, 1999.

5. MEJEAN, A.; VONA, G.; NALPAS, B. y cols.: "Detection of circulating prostate derived cells in patients with prostate adenocarcinoma is an independent risk factor for tumor recurrence". J. Urol., 163: 2022, 2000.

6. KANTOFF, P.W.; HALABI, S.; FARMER, D.A. y cols.: "Prognostic significance of reverse transcriptase polymerase chain reaction for prostatespecific antigen in men with hormone-refractory prostate cancer". J. Clin. Oncol., 19: 3025, 2001.

7. SHARIAT, S.F.; GOTTENGER, E.; NGUYEN, C. y cols.: "Preoperative blood reverse transcriptase-
PCR assays for prostate-specific antigen and human glandular kallikrein for prediction of prostate cancer progression after radical prostatectomy". Cancer Res., 62: 5974, 2002.

8. EDELSTEIN, R.A.; ZIETMAN, A.L.; DE LAS MORENAS, A. y cols.: "Implications of prostate micrometastases in pelvic lymph nodes: An archival tissue study". Urology, 47: 370, 1996.

9. OKEGAWA, T.; NUTAHARA, K.; HIGASHIHARA, E.: "Detection of micrometastatic prostate cancer cells in the lymph nodes by reverse transcriptase-polymerase chain reaction is predictive of biochemical recurrence in pathological stage T2 prostate cancer". J. Urol., 163: 1183, 2000.

10. SHARIAT, S.F.; KATTAN, M.W.; ERDAMAR, S. y cols.: "Detection of clinically significant, occult prostate cancer metastases in lymph nodes using a splice variant-specific RT-PCR assay for human glandular kallikrein”. J. Clin. Oncol., 21: 1223, 2003.

11. SHARIAT, S.F.; ROUDIER, M.P.; WILCOX, G.E. y cols.: "Comparison of immunohistochemistry with reverse transcription-PCR for the detection of micrometastatic prostate cancer in lymph nodes". Cancer Res., 63: 4662, 2003.

**12. FERRARI, A.C.; STONE, N.N.; KUREK, R. y cols.: "Molecular load of pathologically occult metastases in pelvic lymph nodes is an independent prognostic marker of biochemical failure after localized prostate cancer treatment". J. Clin. Oncol., 24: 3081, 2006.

*13. MARTÍNEZ-PIÑEIRO, L.; RIOS, E.; MARTINEZ-GOMARIZ, M. y cols.: "Molecular staging of prostatic cancer with RT-PCR assay for prostate-specific antigen in peripheral blood and lymph nodes: Comparison with standard histological staging and immunohistochemical assessment of occult regional lymph node metastases". Eur. Urol., 43: 342, 2003.

14. ISRAELI, R.S.; MILLER, W.H.Jr.; SU, S.L. y cols.: "Sensitive detection of prostatic hematogenous tumor cell dissemination using prostate specific antigen and prostate specific membrane-derived primers in the polymerase chain reaction". J. Urol., 153: 573, 1995.

15. FREEDLAND, S.J.; SUTTER, M.E.; DOREY, F. y cols.: "Defining the ideal cutpoint for determining PSA recurrence after radical prostatectomy. Prostate-specific antigen". Urology, 61: 365, 2003.

16. CLOBES, H.; FOSSÅ, S.D.; W ÆHRE, H. y cols.: "The immunohistochemical assessment of occult regional lymph node metastases in patients with T3pNoMo prostate cancer before definitive radiotherapy". Br. J. Urol., 85: 270, 2000.

17. FREEMAN, J.A.; ESRIG, D.; GROSSFELD, G.D. y cols.: "Incidence of occult lymph node 
metastases in pathological stage C (pT3No) prostate cancer". J. Urol., 154: 474, 1995.

18. MOUL, J.W.; LEWIS, D.J.; ROSS, A.A. y cols.: "Immunohistologic detection of prostate cancer pelvic lymph node micrometastases: Correlation to preoperative serum prostate-specific antigen". Urology, 43: 68, 1994.

19. GRASSO, Y.Z.; GUPTA, M.K.; LEVIN, H.S. y cols.: "Combined nested RT-PCR assay for prostate-specific antigen and prostate-specific membrane antigen in prostate cancer patients: Correlation with pathological stage". Cancer Res., 58: 1456, 1998.

20. OLSSON, C.A.; DEVRIES, G.M.; RAFFO, A.J. y cols.: "Preoperative reverse transcriptase polymerase chain reaction for prostate specific antigen predicts treatment failure following radical prostatectomy". J. Urol., 155: 1557, 1996.

*21. OKEGAWA, T.; NUTAHARA, K.; HIGASHIHARA, E.: "Preoperative nested reverse transcription-polymerase chain reaction for prostate specific membrane antigen predicts biochemical recurrence after radical prostatectomy". Br. J. Urol., 84: 112, 1999.

22. DEGUCHI, T.; DOI, T.; EHARA, H. y cols.: "Detection of micrometastatic prostate cancer cells in lymph nodes by reverse transcriptase-polymerase chain reaction". Cancer Res, 53: 5350, 1993.

*23. FERRARI, A.C.; STONE, N.N.; EYLER, J.N. y cols.: "Prospective analysis of prostate-specific markers in pelvic lymph nodes of patients with high-risk prostate cancer". J. Natl. Cancer Inst., 89: 1498, 1997.

24. LIN, D.W.; ELLIS, W.J.; TRUE, L.D. y cols.: "Reverse transcriptase-polymerase chain reaction (RT-PCR) for detection of prostate cancer micrometastases in pelvic lymph nodes (LN), bone marrow (BM) and peripheral blood (PB)". J. Urol., 161: 908, 1999.

25. FERRARI, A.C.; STONE, N.N.; WALLACE, W. y cols.: "Rerverse transcriptase-polymerase chain reaction (RT-PCR) for prostate specific antigen (PSA) in pelvic lymph nodes (PLN) of men with localized prostate cancer: Correlation with risk factors and PSA failure". J. Urol., 163: 824, 2000.

26. MAO, H.; HOSHI, S.; TAKAHASHI, T. y cols.: "Detection of PSA mRNA from the peripheral blood and pelvic lymph nodes in patients with prostatic cancer by means of reverse transcription-polymerase chain reaction (RT-PCR)". Nippon Hinyokika Gakkai Zasshi, 89: 596, 1998.

27. OKEGAWA, T.; NODA, H.; KATO, M. y cols.: "Value of reverse transcription polymerase chain reaction assay in pathological stage T3No prostate cancer". Prostate, 44: 210, 2000.

28. POTTER, S.R.; MANGOLD, L.A.; SHUE, M.J. y cols.: "Molecular and immunohistochemical staging of men with seminal vesicle invasion and negative pelvic lymph nodes at radical prostatectomy". Cancer, 89: 2577, 2000.

29. KATZ, A.E.; DE VRIES, G.M.; BEGG, M.D. y cols.: "Enhanced reversed transcriptase-polymerase chain reaction for prostate specific antigen as an indicator of true pathologic stage in patients with prostate cancer". Cancer, 75: 1642, 1995.

30. THOMAS, J.; GUPTA, M.; GRASSO, Y. y cols.: "Preoperative combined nested reverse transcriptase polymerase chain reaction for prostatespecific antigen and prostate-specific membrane antigen does not correlate with pathologic stage or biochemical failure in patients with localized prostate cancer undergoing radical prostatectomy". J. Clin. Oncol., 20: 3213, 2002.

31. ELLIS, W.J.; PFITZENMAIER, J.; COLLI, J. y cols.: "Detection and isolation of prostate cancer cells from peripheral blood and bone marrow". Urology, 61: 2277, 2003.

32. HEID, C.A.; STEVENS, J.; LIVAK, K.J. y cols.: "Real-time quantitative PCR". Genome Res., 6: 986, 1996. 